\section{On the Path to Innovation: Analysis of Accounting Companies Innovation Capabilities in Digital Technologies}

\author{
Giovana Sordi Schiavi ${ }^{1}$ \\ Fernanda da Silva Momo ${ }^{1}$ \\ Antonio Carlos Gastaud Maçada ${ }^{1}$ \\ ${ }^{1}$ Federal University of Rio Grande do Sul (UFRGS), Business School, \\ Administration Department, Porto Alegre, Brazil
}

\section{Ariel Behr'}

${ }^{2}$ Federal University of Rio Grande do Sul (UFRGS), Economics College, Department of Accounting and Actuarial Sciences, Porto Alegre, Brazil

\begin{abstract}
Purpose - This article examines the innovation capability of accounting firms in the Brazilian market, in their use of digital technologies, based on technology development, operation, management, and transaction capabilities.
\end{abstract}

Design/methodology/approach - We carried out interviews with the main managers of the companies and collected institutional documents and external documents on the national and international context of accounting business innovation.

Findings - Accounting has begun on the traditional path towards digital innovation, demonstrating the quality and value that technology-related solutions can generate when exploited in business and especially in processes. This increase in technology causes changes in accounting business models.

Originality/value - The paper contributes to the theoretical body of work on innovation and accounting, identifying that this area is on the way towards innovation by using new technologies in the creation of operations and transaction management. It is clear that the process of innovation and digital transformation already presents a real challenge to be managed.

Keywords - Accounting; Innovation; Business Models; Digital Technologies.
Recebimento:

08/10/2018

Aprovaçáo:

$11 / 06 / 2019$

Editor responsável:

Prof. Dr. Ivam Ricardo Peleias

Avaliado pelo sistema:

Double Blind Review

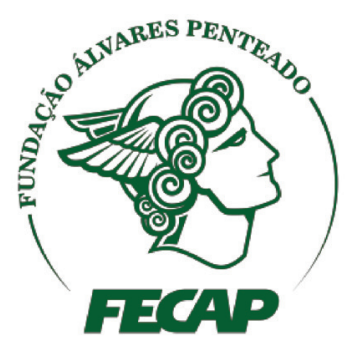

Revista Brasileira de Gestáo de Negócios 


\section{Introduction}

The central role of digital technologies in changing societies and the business environment has aroused managers' interest in dealing with innovation and the creation of digital products, services, and processes (Nylén \& Holmström, 2015). According to the Accenture Digital Density Index survey, this growing trend towards the use of digital technologies in different products and services will add more than $\$ 1$ trillion to global economic activity by 2020 (Accenture, 2015). With the rapid change of the business environment as digital technologies have been introduced, their integration into business processes has proven to be essential for contemporary organizations looking to address challenges and create opportunities for competitive advantage in a digital economy (Liu, Chen, \& Chou, 2011; Tongur \& Engwall, 2014).

In this regard, the MIT Sloan Management Review survey in conjunction with Deloitte found that nearly $90 \%$ of managers report experiencing the impact of digital technologies on their industries; however, less than half report doing enough to prepare for this digital revolution (Kane, Palmer, Phillips, Kiron, \& Buckley, 2015). In this context, different business areas, especially the traditional ones, face one of the most challenging periods in the market (Guthrie \& Parker, 2016), and the accounting sector is an example of a segment that has been disturbed due to the new digital technologies that are changing accounting activities (Pan \& Seow, 2016). Fawcett (2015) points out that different digital technologies will significantly impact accounting services in the coming years, revealing their leading role in the process of changing the accounting market. This is because many routine accounting processes can be replaced by different digital technologies, which allow greater flexibility, agility, and security in daily actions (Bygren, 2016).

According to the Cokins and Angel (2017) report on the disruptive impact on accounting, routine tasks performed by accounting professionals such as data entry and bookkeeping are work processes that are increasingly vulnerable to digitization and automation. Digital technologies create opportunities to provide quality, high value-added solutions, rather than just reporting information after the fact has occurred and complying with legal obligations (Baron, 2016; Basova, 2017). Understanding the changes in the accounting market and their influences on business is fundamental to ensure the survival of companies operating in this area (Frey \& Osborne, 2013). This forces accounting businesses to position themselves not only in relation to the introduction of new technologies, but also in relation to changes in services and products offered as well as to strategic business elements (Bygren, 2016).

Due to the arrival of digital technologies in accounting functions, the demand for skills related to the best use of these technologies has been growing among business and accounting professionals (Pan \& Seow, 2016). Guthrie and Parker (2016) point out that accounting professionals will be challenged to go beyond the traditional skills used to perform mandatory and routine tasks, looking for new ways to create value for customers that ensure business sustainability through the exploration of new digital technologies. This is because these technologies allow the orchestration of new products, processes, services, platforms, and even new business models, enabling the digital innovation process (Nambisan, Lyytinen, Majchrzak, \& Song, 2017). Given this current context, the development of innovation capability in accounting firms is critical, as it presses businesses in the area to pursue continuous innovation in response to the changing environment (Slater, Hult, \& Olson, 2010), with digital technologies being the key major drivers of these environmental transformations.

Along these lines, the ability to innovate enables businesses to unite technological efforts with improved firm performance and can be seen as a global ability to absorb, adapt, and transform 
particular technology into specific managerial, operations, and transaction routines, which drives innovation and competitive advantage (Zawislak, Alves, Tello-Gamarra, Barbieux, \& Reichert, 2012). In light of this, this article presents the following research question: How is capability for innovation exploited by companies from different accounting sectors, using digital technologies? Thus, the objective is to examine the innovation capability of accounting firms in the Brazilian market that use digital technologies focusing on technology development, operations, managerial, and transaction capabilities. These capabilities are verified in the framework of Zawislak et al. (2012), which groups them into business and technology-driven capabilities. To do so, a multiple case study was conducted with six prominent companies operating in different areas of accounting. Interviews were conducted with the main managers of these companies and institutional documents were collected. Moreover, other external documents about the national and international context of accounting business innovation were collected to support the proposed analyses. Data were analyzed using the Nvivo 11 software, with content analysis using codes from the innovation capabilities framework.

Guthrie and Parker (2016) point out that it is necessary to pay attention to this emerging accounting scenario due to changes in the accounting business caused by the introduction of new technologies and digital innovations in the market. Thus, this research aims to present a better understanding of the innovation capabilities of accounting firms, which exploit digital technologies in their business, by analyzing leading companies in today's market. These analyses provide the field and managers with a more comprehensive overview of the accounting context, since they portray aspects of management and business innovation that are references in the current accounting market. Moreover, this research aims to contribute to the theory by presenting an empirical study on innovation capabilities in accounting firms, where the conservatism of the profession and the aversion to changes in business conduct are aspects that distance innovation from the accounting context (Chang, Hilary, Kang, \& Zhang, 2013), an aspect also found in the literature on the subject.

\section{Background}

\section{I Innovation and Digital Transformation}

Digital technologies are being incorporated into a wide range of products and services, and are present in individuals' social, personal, and work relationships (Nambisan, 2013). In this context, the way digital technologies are being employed in different products and services ends up influencing and changing business (Demirkan, Spohrer, \& Welser, 2016). This is occurring as digital technology is increasingly being introduced and exploited in business to meet the different goals of organizations, leading to profound changes across entire industries (Nylén \& Holmström, 2015).

Therefore, companies today face the challenge of innovation and digital transformation. While digital innovation is characterized by the creation of new products, services, and processes, among others, digital transformation combines the effects of various digital innovations, bringing new agents, structures, practices, values, and beliefs that change, threaten, replace, or complement existing rules within organizations and industries (Hiningsa, Gegenhuberb, \& Greenwoodaa, 2018). As a result, digital technologies open up new business opportunities, but they also create competitive pressure (Abrell, Pihlajamaa, Kanto, Brocke, \& Uebernickel, 2016), stimulating the digital innovation of products and services. Nylén and Holmström (2015) reveal that the potential of digital technologies to generate innovative products and services that enable managers to achieve a competitive advantage in the marketplace arouses their interest in addressing the challenges behind innovation and digital transformation. 
To overcome these challenges, it is essential to develop strategies that seek new ways of integrating and using digital technologies in business (Hess, Matt, Wiesböck, \& Benlian, 2016). Therefore, companies need to create strategies and management forms for the changes that come with innovation and digital transformation (Nylén \& Holmström, 2015). However, this is not a simple task for companies operating in the "pre-digital" economy that today need to adapt to the digital economy (Sebastian et al., 2017). It is observed that companies should not assume reactive behaviors only when new technologies are introduced, but also act on their strategic business elements, from operational to managerial, in order to contribute to the business innovation process. One way to organize the analysis of business models and innovations can be found in the Business Model Canvas tool. This model organizes strategy analysis by taking the following into account: the 'customer segment' served, the 'distribution channels' of products/services, the form of 'relationship' and communication of a company with its customers, the 'revenue generation' strategy, the description of the main 'resources, processes, and partners' in carrying out the company's activities, and a further description of the 'cost' structure required; so that in the end it is possible to indicate which 'value proposition' the company wants to deliver to its customers (Osterwalder \& Pigneur, 2011).

In order to investigate how companies organize themselves to enter the digital economy, Sebastian et al. (2017) analyzed 25 firms that were introducing the process of innovation and digital transformation in their business. The authors identified that strategies aimed at providing digitized solutions and customer engagement enabled these companies to enter the process of innovation and digital business transformation. In addition, the authors pointed out that the digital technologies needed to execute these strategies would be digital service platforms (which support business agility and rapid innovation) and digital technologies for business operations (which support efficiency and operational excellence). This case reveals how companies established in the "pre-digital" economy can compete in digitized environments by pointing out that digital innovation is an organizational capability that can be developed by any company today.

\subsection{Innovation Capability}

Innovation has always been related to the achievement of competitive advantage, which is usually attained when organizations develop their technological capabilities (Kim, 1999; Afuah, 2002; Reichert et al., 2011; Zawislak et al., 2012). However, as highlighted by Zawislak et al. (2012), not all companies that invest in technological capability are innovative, just as organizations that invest little in technological resources may present innovative performance. In this sense, it is emphasized that innovation capability is the meta-capability that can best explain innovation and the achievement of competitive advantage, becoming crucial for the achievement of the latter when highly unstable market conditions exist (Ramanathan \& Hui, 2018).

Thus, it is understood that capability for innovation pressures organizations into continuously developing innovations in response to the changing environment (Slater, Hult, \& Olson, 2010). This is because capability for innovation is embedded in all strategies, systems, and structures that support innovation in an organization (Gloet \& Samson, 2016). Laforet (2011) points out that innovation only happens when the company has the ability to innovate, making it a valuable asset for organizations to provide and sustain competitive advantage (Rajapathirana \& Hui, 2018). Innovation capability makes it easy for companies to introduce new products and services, and innovation performance can be explained as a combination of assets and resources (Guan \& Ma, 2003; Lawson \& Samson, 2001).

Given these concepts, we have in the literature the framework developed by Zawislak et al. (2012) regarding innovation capability (Figure 1). In this model, the organizational overview 
is based on two complementary theoretical approaches: Transaction Cost Theory, which conceptualizes the organization as a relationship of contracts (treaties) that have certain limits and are in accordance with a certain governance structure (Coase, 1937; Williamson, 1985); and Capability Theory, which conceptualizes the organization as a union of resources, knowledge, experience, skills, and routines (Richardson, 1972; Chandler, 1992).

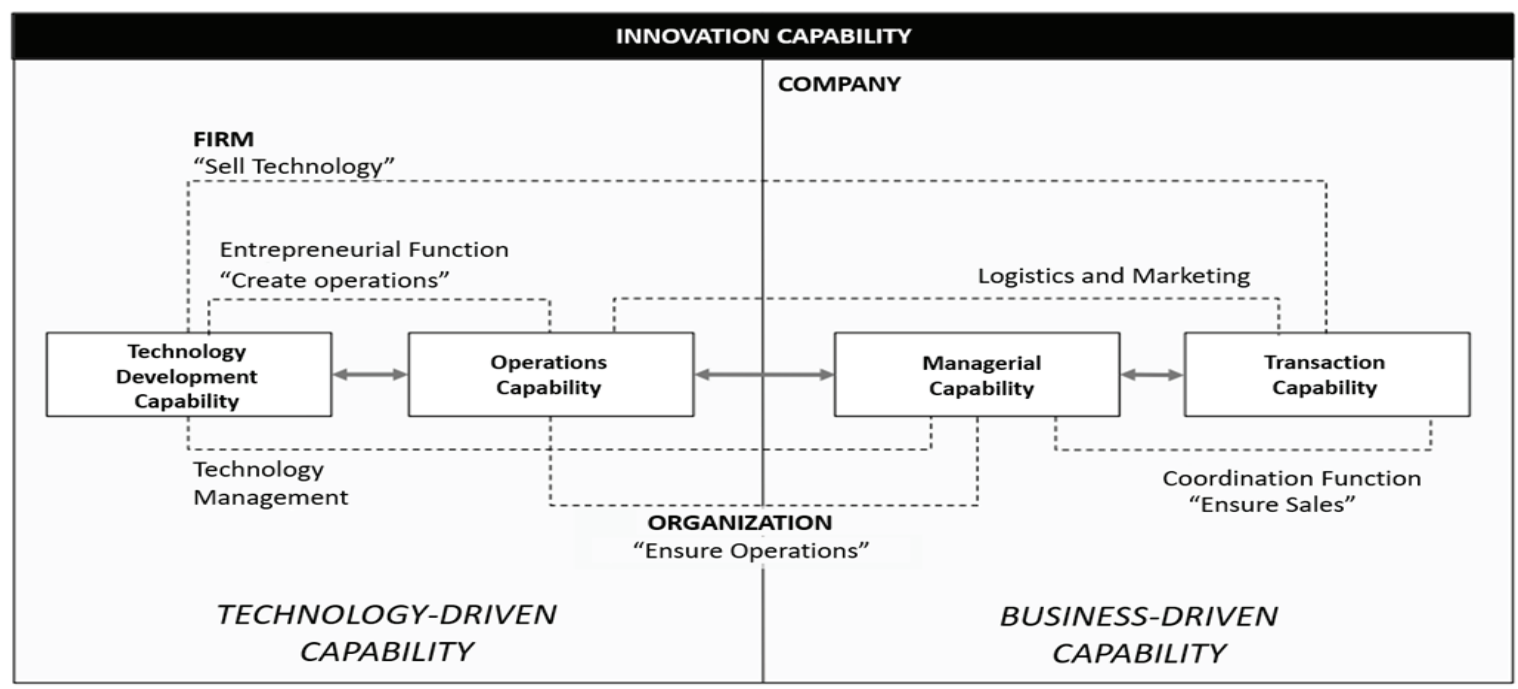

Figure 1. Innovation Capability Framework.

Source: Retrieved from "Innovation capability: From technology development to transaction capability," by P. A. Zawislak, A. C. Alves, J. Tello-Gamarra, D. Barbieux, \& F.M. Reichert, 2012, Journal of Technology Management and Innovation, 7, p. 17.

For the construction of the framework the authors gather the concepts related to innovation capability and emphasize that it must be understood as a meta-capability incorporated into four different complementary capabilities: technology development capability; operations capability; managerial capability; and transaction capability (Table 1 ). Thus, capability is a technological learning process translated into technology development and operations capabilities, supported by managerial and transactional routines (Zawislak et al., 2012). 
Table 1

\section{Definition of innovation capabilities}

\begin{tabular}{|c|c|c|}
\hline Capability & Definition & Type of Innovation \\
\hline \multirow[b]{2}{*}{ Technology Development } & \multirow[b]{2}{*}{$\begin{array}{l}\text { Anyone's ability to interpret the current } \\
\text { state of the art and absorb and eventually } \\
\text { transform a technology to create or alter } \\
\text { its capability to operate, as well as any } \\
\text { other capability to achieve higher levels of } \\
\text { technical and economic efficiency. }\end{array}$} & Technological Innovation \\
\hline & & $\begin{array}{l}\text { This type of innovation encompasses the development of new } \\
\text { designs, new materials, and new products. In addition, it } \\
\text { includes the development of machinery, equipment, and new } \\
\text { components. }\end{array}$ \\
\hline \multirow[b]{2}{*}{ Operations } & \multirow[b]{2}{*}{$\begin{array}{l}\text { The ability to execute productive capability, } \\
\text { which is shown through the assortment } \\
\text { of daily routines that are embodied in } \\
\text { knowledge, skills, and technical systems at } \\
\text { any given time. }\end{array}$} & Operational Innovation \\
\hline & & $\begin{array}{l}\text { This type of innovation encompasses new processes, } \\
\text { improvements to existing processes, the introduction of } \\
\text { modern techniques, new layouts, etc. It allows the company } \\
\text { to produce with quality, efficiency, and flexibility at the lowest } \\
\text { possible cost. }\end{array}$ \\
\hline \multirow[b]{2}{*}{ Managerial } & \multirow[b]{2}{*}{$\begin{array}{l}\text { The ability to transform the result of } \\
\text { technological development into coherent } \\
\text { operations and transaction arrangements. }\end{array}$} & Managerial Innovation \\
\hline & & $\begin{array}{l}\text { This type of innovation encompasses the development of } \\
\text { management skills that reduce "internal friction" between } \\
\text { different areas of the company. It aims to create new } \\
\text { management methods and new business strategies and } \\
\text { improve decision making and cross-functional coordination. }\end{array}$ \\
\hline \multirow[b]{2}{*}{ Transaction } & \multirow[b]{2}{*}{$\begin{array}{l}\text { The ability to reduce marketing, } \\
\text { outsourcing, trading, logistics, and delivery } \\
\text { costs; in other words, transaction costs. }\end{array}$} & Transaction Innovation \\
\hline & & $\begin{array}{l}\text { This type of innovation involves developing ways to minimize } \\
\text { costs in transactions with suppliers and customers. It is sought } \\
\text { to create new business strategies, improve relationships with } \\
\text { suppliers, streamline market knowledge, etc. }\end{array}$ \\
\hline
\end{tabular}

Note. Adapted from "Innovation and dynamic capabilities of the firm: Defining an assessment model” by D. Barbieux, F. M. Reichert, J. Tello-Gamarra, \& P. A. Zawislak, 2017, Revista de Administração de Empresas, 57; and from "Influences of the internal capabilities of firms on their innovation performance: A case study investigation in Brazil” by Zawislak P. A., A. C. Alves, J. Tello-Gamarra, D. Barbieux, \& F. M. Reichert, 2013, International Journal of Management, 30.

The innovation capability framework presents these four capabilities as complementary capabilities relating to innovation capability, indicating that in order to achieve innovation, it is necessary to build such a set of complementary capabilities (Guan \& Ma, 2003; Zawislak et al., 2013). Thus, the structure of the innovation capability framework, based on technology, operations, managerial, and transaction capabilities, synthesizes the main organizational aspects that support innovation, with innovation capability being present in each one of them (Lawson \& Samson, 2001; Guan \& Ma, 2003; Gloet \& Samson, 2016). The framework by Zawislak et al. (2012) also reveals that these four complementary capabilities are divided into two groups, corresponding to their focus: i) technology-driven, which represent the firm's accumulated experience in technical changes and production processes; and ii) business-driven, which denotes the assembly of organizational and transactional routines.

Based on a case study of four organizations to assess their innovation capabilities, Zawislak et al. (2013) identified that all the organizations analyzed had the four proposed capabilities, and that one of them predominated over the others, thus characterizing the innovativeness of each organization. Moreover, it was possible to see the need of the organization, over time, to change its technological, managerial, operational, or transactional knowledge, in order to perpetuate in a particular market. Therefore, to innovate, an organization's capabilities need to be specific and integrated to generate income during the period between the introduction of an innovation and its successful diffusion (Zawislak et al., 2013). 


\section{Method}

This qualitative and descriptive research performs a multiple case study examining the innovation capability of accounting firms in the Brazilian market stemming from the use of digital technologies, based on technology development, operations, managerial, and transaction capabilities. The multiple case study involves the individual study of each company operating in one accounting area, allowing for the verification of similarities and differences between the businesses analyzed within the same context (Yin, 2015). The units of analysis were prominent companies operating in the Brazilian market in different areas of accounting, which have innovative characteristics in their business, namely: financial, managerial, tax, systems, forensic, and auditing. Note that the choice of one company in each area was due to the diversity of accounting businesses, which are characterized according to the areas of expertise in accounting. It also warrants mentioning that the public and academic areas were not analyzed because they do not fit the scope of the research, which describes business models.

The units of analysis were selected for their prominence on a national level, and obtained through open Google searches and expert referrals, not being limited to any region of the country. Google searches were performed using the terms 'inovação nos modelos de negócios contábeis' ('innovative in accounting business models') and the possible derivations 'modelo de negócio disruptivo' and 'novo modelo de negócio' ('disruptive business model' and 'new business model') and accounting, or one of its areas (financial, managerial, tax, systems, forensic, and auditing), without quotation marks. From these searches, we identified 3 companies that showed potential characteristics of innovation in their business (financial, tax, and systems), based on the descriptions provided by the companies about their business. The second technique involved the contribution of six specialists (academic professionals with market experience in each area) to choose accounting firms with the potential for innovation in their business, considering their experience in the accounting market. In this stage, 3 companies (managerial, forensic, and auditing) were selected, which, according to the experts interviewed, have characteristics of innovation, thus being relevant for analysis in this study.

The units of analysis were six accounting companies, with headquarters located in the southern region of Brazil, but operating nationwide. After defining the units of analysis, we started to collect data. There are several ways to collect data in a case study, and combining more than one type of collection technique in the same study is indicated (triangulation of data collection techniques) as it contributes to the breadth and validity of the research construct (Flick, 2009; Yin, 2015). In-depth semi-structured interviews were conducted with the main managers of the six companies. Since the objective was to examine innovation capability in the business models, it was important to know the company decision makers' views and the structuring of the business model strategies. Institutional/internal documents were also collected, composed of formalized communications on the institutional websites, other websites, blogs, magazines, and reports, where the company itself highlights the elements of its strategy (which may differ from those verified in the interviews, thus justifying the triangulation strategy). In addition, 47 external documents were collected to complement the data with formalized third party communications about companies and the national and international context of innovation in the accounting business. Those external documents were selected through Google searches using the terms 'innovation in accounting business models' (7 search pages on Google) and 'innovation in accounting business models' (31 search pages on Google; after page 15, there was data saturation), without quotation marks.

All these different data collection techniques enabled data triangulation for analysis, which is essential for case studies and 
for the rigorous strategy of qualitative research (Flick, 2009; Yin, 2015). In addition, note that the data collection strategy of this article focused on the research question and the diversity of data collection sources, as indicated by Eisenhardt (1989) and Mintzberg (1979), who reveal that it is not the sample size that defines the quality of a case study and its contribution to theory. Therefore, data collection strategies should be defined in order to answer the research question, preventing the researcher from being overwhelmed by the volume of data (Eisenhardt, 1989; Mintzberg, 1979).

The interviews were conducted in the second half of 2017, and the interview script was prepared based on the literature on business model innovation, which uses the elements of innovation capabilities as its basis and addresses the relevance of digital technologies in the innovation process, as well as on the work of Osterwalder and Pigneur (2011) on strategic elements of business models (Business Model Canvas). The choice of these elements took into consideration the results of Bonazzi and Zilber (2014), who characterized a company's innovation process, linking it to the concepts of organizational and business model development strategies. This roadmap allowed for the identification of the practices of each organization analyzed, serving as a basis for the analysis of innovation capabilities.

After collecting this material, the data were processed and analyzed. The interviews were recorded and transcribed to allow for better treatment and manipulation of the material, using the data processing software Nvivo 11 . Documentary data were also processed and manipulated in Nvivo 11, in order to enable a contextual analysis of the innovation trends in accounting business models. For the analysis of the interview data, we used content analysis, seeking to describe the meaning of the qualitative data by assigning codes to the material collected in a coding framework (or code book) that presents all aspects of description and interpretation (Schreier, 2013), as shown in Appendix 2. The coding framework was built from codes derived from the literature on innovation capabilities by Zawislak et al. (2012) and the literature on the strategic elements of business models (Osterwalder \& Pigneur, 2011). During the content analysis, the initial codes based on the literature were refined, elaborated on, and related or interconnected, so axial categorization was used in this research (Gibbs, 2009).

\section{Results}

The results are organized in order to present, according to the analysis of the strategic elements of the innovative business models of the companies studied, the innovation capabilities based on the framework of Zawislak et al. (2012), which are: technology development, operations, managerial, and transaction. To represent the reports of the six managers of the companies studied, the following code was used: G_fin to refer to the financial area manager, G_man for the managerial area one, G_tax for the tax area one, $G \_s y s$ for the systems area one, $G$ for to the forensic area one, and G_aud for the audit area manager.

\section{I Financial Accounting Company}

As noted in the institutional documents, the company in the area of financial accounting has been in the market for 5 years and has excelled in providing accounting services to clients. As with other accounting firms operating in this area, G_fin points out that the company provides all services necessary to maintain customer accounting, meeting the required legal obligations: "we have to deliver all that is required by law, by the government, to the customer, so we perform all the necessary obligations, bookkeeping, tax calculations, everything." However, this company differentiates itself by focusing on a specific customer segment (micro and small companies), providing its services in a fully online manner and at low cost. Table 2 illustrates the strategic elements identified in the company, which allow us to evaluate the way the company organizes and structures its business. 
Table 2

Strategic elements of the financial accounting business model

\begin{tabular}{|c|c|c|c|c|c|c|c|c|}
\hline $\begin{array}{l}\text { Customer } \\
\text { Segments }\end{array}$ & $\begin{array}{c}\text { Customer } \\
\text { Relationship }\end{array}$ & Channels & $\begin{array}{c}\text { Key } \\
\text { Features }\end{array}$ & Key Activities & $\begin{array}{c}\text { Key } \\
\text { Partnerships }\end{array}$ & $\begin{array}{c}\text { Cost } \\
\text { Structure }\end{array}$ & $\begin{array}{l}\text { Revenue } \\
\text { Sources }\end{array}$ & $\begin{array}{c}\text { Value } \\
\text { Proposition }\end{array}$ \\
\hline $\begin{array}{l}\text { Micro } \\
\text { and Small } \\
\text { Businesses }\end{array}$ & $\begin{array}{l}\text { Near and } \\
\text { digital }\end{array}$ & $\begin{array}{l}\text { Online } \\
\text { platform }\end{array}$ & $\begin{array}{c}\text { Technology } \\
\text { and } \\
\text { personnel }\end{array}$ & $\begin{array}{l}\text { Platform } \\
\text { enhancement, } \\
\text { customer } \\
\text { service, and } \\
\text { compliance } \\
\text { with legal } \\
\text { obligations }\end{array}$ & $\begin{array}{l}\text { Not } \\
\text { highlighted }\end{array}$ & $\begin{array}{l}\text { Personnel } \\
\text { and } \\
\text { technology }\end{array}$ & $\begin{array}{l}\text { Monthly } \\
\text { payment } \\
\text { ("package") }\end{array}$ & $\begin{array}{c}\text { Agility and } \\
\text { simplicity in } \\
\text { performing } \\
\text { legal } \\
\text { obligations }\end{array}$ \\
\hline
\end{tabular}

The use of different digital technologies (notably cloud technologies and digital platforms for communication and document transfer) has enabled the company to change its strategies and business model to fully operate online and bring more accessibility and agility in providing accounting services to the client segment with which the company operates (Demirkan et al., 2016; Pan \& Seow, 2016; Sebastian et al., 2017). G_fin points out that "it was through new technologies that we were able to offer the service we offer today, in the cloud, to thousands of companies and in various cities across the country, which was not possible before without these technologies."

Thus, the company's technology development capability is noteworthy: "we work a lot with technology, we invest heavily in technology, and we believe technology is what differentiates us from our competitors" (G_fin). This capability enables the company to use digital technologies for strategic purposes, primarily modifying its processes to provide a new service, which is fully online and different from that of the competition. As highlighted by Zawislak et al. (2012), technology development capability is a result of the learning process in which companies internalize new knowledge to produce technological changes that lead to new products and services.

The ability to work these technologies properly in order to produce marketable goods and services is also identifiable within the enterprise. This capability requires companies to implement production systems that are appropriate for the products or services offered, for the company's capacity, and for customer needs (Zawislak et al., 2012). In this sense, G_fin highlights that the key operational processes are the "development of the platform, which is used to deliver the service to the customer, and the client assistance, which is very important," and is also performed by digital platforms. Note that the production system is structured around the developed digital platforms, which facilitate the work of the accounting team responsible for the supervision and execution of accounting services. This structure allows the company to offer an accounting service to more than 10,000 customers at an average price of $\mathrm{R} \$$ 190 (\$ 45), which is well below the market price. This enables the business to be scalable, ensuring cost savings, flexible actions and, consequently, speedy responses to customers and greater total revenue.

Regarding managerial capability, G_fin emphasizes that management actions are focused not only on administrative issues, but mainly on improving the service provided, seeking better ways to use platforms that reflect the service delivered to the customer and the innovation continuity: "we are always working to ensure we do a good job in delivering accounting to micro and small companies." Regarding transaction capability, G_fin points out that the structuring of the business around digital platforms, which allows the company to offer scalable and low cost online services, enabled the firm to provide its clients with "more simplicity, practicality, and especially savings.” 
Thus, it is noted that the company has a combination of the four capabilities analyzed, with the technology development, operations, and transaction capabilities being more impactful in the company, ensuring that the company is in fact innovative, since at least one of the four capabilities is predominant. These results are in agreement with the findings of Zawislak et al. (2012), which show that innovative companies that have a predominance of technology development or operations capabilities at the beginning of their activities may need to develop other capabilities (managerial and transaction) as the market matures. Note that this shift to other capabilities can come from the company itself, regardless of market dynamics (Zawislak et al., 2012).

In short, the company analyzed has technology-driven capabilities. It is possible to observe the 'entrepreneurial feature' in the company, which is verified by the relationship between technology development and operations capabilities (Zawislak et al., 2012). This reflects the fact that the exploration of new technologies allows for the creation of new operations, contributing to the company's innovativeness.

\subsection{Managerial Accounting Company}

The company analyzed stands out in the market by offering management consulting services for micro and small companies for over 10 years, according to institutional documents presented. Typically, managerial accounting services are not accessible to this market segment because of the price charged for this type of service. However, by using digital communication and management platforms and restructuring business configurations, the company was able to innovate in the managerial area, making the service faster, agile, and cheaper: "in our company, we have process and management model innovation" (G_man), corroborating the findings of Sebastian et al. (2017). Table 3 illustrates the strategic elements of the company analyzed.

Table 3

Strategic elements of the managerial accounting business model

\begin{tabular}{|c|c|c|c|c|c|c|c|c|}
\hline $\begin{array}{l}\text { Customer } \\
\text { Segments }\end{array}$ & $\begin{array}{c}\text { Customer } \\
\text { Relationship }\end{array}$ & Channels & $\begin{array}{c}\text { Key } \\
\text { Features }\end{array}$ & $\begin{array}{c}\text { Key } \\
\text { Activities }\end{array}$ & $\begin{array}{c}\text { Key } \\
\text { Partnerships }\end{array}$ & $\begin{array}{c}\text { Cost } \\
\text { Structure }\end{array}$ & $\begin{array}{l}\text { Revenue } \\
\text { Sources }\end{array}$ & $\begin{array}{c}\text { Value } \\
\text { Proposition }\end{array}$ \\
\hline $\begin{array}{c}\text { Micro } \\
\text { and Small } \\
\text { Businesses }\end{array}$ & $\begin{array}{c}\text { Close } \\
\text { proximity } \\
\text { between } \\
\text { company and } \\
\text { customer to } \\
\text { understand } \\
\text { customer } \\
\text { needs }\end{array}$ & $\begin{array}{l}\text { Online } \\
\text { platform, } \\
\text { phone, in } \\
\text { person, and } \\
\text { other media }\end{array}$ & $\begin{array}{l}\text { Technology } \\
\text { and } \\
\text { personnel }\end{array}$ & $\begin{array}{l}\text { Organization } \\
\text { and access to } \\
\text { information, } \\
\text { analysis, and } \\
\text { reporting }\end{array}$ & $\begin{array}{c}\text { Partnerships } \\
\text { with } \\
\text { universities } \\
\text { and } \\
\text { incubators }\end{array}$ & $\begin{array}{l}\text { Personnel } \\
\text { and } \\
\text { technology }\end{array}$ & $\begin{array}{c}\text { Technical } \\
\text { hours }\end{array}$ & $\begin{array}{c}\text { Support in } \\
\text { decision } \\
\text { making }\end{array}$ \\
\hline
\end{tabular}

When assessing these strategic elements, we once again note the presence of digital technologies supporting the business. Such technologies employed in accounting routines allow work processes to be more dynamic and secure (Bygren, 2016). The technology development capability of this company was most evident at the beginning of the company's operations, when technologies were installed and exploited within the business: "since I started the company I have spent a lot on technology, [...] because I always wanted the BEST technology [...], so I wanted the cloud, I wanted all document management in the cloud, and nobody used it" (G_man).

The company's operations capability is seen more prominently in the business today as it seeks to efficiently employ the technology 
used to improve the quality of service provided (Zawislak et al., 2012). According to G_man, "technology is fundamental to the work we do and it is fundamental as a means. For example, the relationship channel we use is an online platform where the customer logs in and places their entire request, and we have a maximum of 24 hours to answer." In this case, the company organized its operations and staff so that they are always prepared to receive any kind of customer request. To do so, the company makes each of its employees responsible for a small client portfolio (account manager), allowing that professional to have a complete and in-depth view of all the companies in their portfolio.

This is made possible by the managerial capability of the organization, which sought new management methods and new business strategies, improving cross-functional coordination (Zawislak et al., 2013; Alves et al., 2017): "I have worked in others offices, so I saw that people wanted to deliver what they wanted, and the customer didn't want what was being delivered, so we reversed that logic, we listen to the customers and deliver what they want, [...] it was a business change" (G_man). Regarding transaction capability, it is noted that the company has been looking for new business strategies, especially when dealing with public universities and incubators: "I have extremely traditional clients, who like my service delivery model, but I also have a portion of customers who could no longer see value in that accounting model, which is delivering things that don't make sense to them" (G_man).
It is observed that the company has a combination of the four capabilities analyzed. However, operations and managerial capabilities are more impactful across the business, ensuring that the business is innovative. These results are in agreement with the findings of Zawislak et al. (2012), showing that at the beginning of the activities of the company analyzed, the technology development capability predominated, then that capability migrated to operations and managerial capabilities according to changes that the company deemed necessary for the business. In this case, it is noted that the capabilities of the company analyzed are more focused on business, although there are still technology-driven traits. It is also possible to perceive the "operations guarantee," observed in the relationship between operations and managerial capabilities (Zawislak et al., 2012).

\subsection{Tax Accounting Company}

As noted in the institutional documents, the company analyzed has been in the market for over 5 years and stands out for offering services related to tax strategy, such as mapping tax opportunities and automatic monitoring of tax rules, which are supported by the intense use of digital technologies (anticipatory activities). This allows the company to differentiate itself from other businesses in the area, which focus on tax credit recovery and tax review activities (reactive activities). Table 4 illustrates the strategic elements identified in the company.

Table 4

Strategic elements of the tax accounting business model

\begin{tabular}{|c|c|c|c|c|c|c|c|c|}
\hline $\begin{array}{l}\text { Customer } \\
\text { Segments }\end{array}$ & $\begin{array}{c}\text { Customer } \\
\text { Relationship }\end{array}$ & Channels & $\begin{array}{c}\text { Key } \\
\text { Features }\end{array}$ & Key Activities & $\begin{array}{c}\text { Key } \\
\text { Partnerships }\end{array}$ & $\begin{array}{c}\text { Cost } \\
\text { Structure }\end{array}$ & $\begin{array}{l}\text { Revenue } \\
\text { Sources }\end{array}$ & $\begin{array}{c}\text { Value } \\
\text { Proposition }\end{array}$ \\
\hline $\begin{array}{c}\text { Middle market } \\
\text { companies }\end{array}$ & $\begin{array}{l}\text { Close customer } \\
\text { proximity for } \\
\text { tax strategies }\end{array}$ & $\begin{array}{l}\text { Email, in } \\
\text { person, } \\
\text { phone, and } \\
\text { other media }\end{array}$ & $\begin{array}{l}\text { Technology } \\
\text { and } \\
\text { personnel }\end{array}$ & $\begin{array}{c}\text { Project } \\
\text { management } \\
\text { (project } \\
\text { preparation, } \\
\text { planning, and } \\
\text { execution) }\end{array}$ & $\begin{array}{c}\text { Accountants } \\
\text { and } \\
\text { collaborative } \\
\text { network } \\
\text { among } \\
\text { associates }\end{array}$ & $\begin{array}{l}\text { Personnel, } \\
\text { technology, } \\
\text { and physical } \\
\text { structure }\end{array}$ & $\begin{array}{l}\text { Technical } \\
\text { hours or a } \\
\text { percentage } \\
\text { of the } \\
\text { results }\end{array}$ & $\begin{array}{c}\text { Tax strategy } \\
\text { (financial } \\
\text { effect) }\end{array}$ \\
\hline
\end{tabular}


As noted by G_tax, the company performs "technology-based tax accounting, [...] using database, artificial intelligence in programming, systematic barcode taxation, QR Code taxation of some products, which governments might end up using in the future." Thus, the technology development capability stands out, which allows the company to use several digital technologies for strategic purposes, mainly modifying its processes to offer a new service unlike that offered by the competition.

In this case, the operating capability to work with these technologies is also identifiable within the company, requiring the implementation of production systems suitable for the execution of services (Zawislak et al., 2012). G_tax points out that working with "a platform that runs a web service, a computing engine that works around the clock [...]" is essential because the company can capture data and information from customers at any time. This allows accounting advisors to always have access to up-to-date information for executing tax strategies quickly and proactively.

Along these lines, the managerial capability can also be observed within the company, which seeks to adapt the business by valuing new management methods and business strategies that ensure business innovativeness: "to work with a digital model, you have to be prepared to be open-minded to change everything you have seen in traditional terms, you have to think about technology and about people, [...] if you don't have these, it doesn't work" (G_tax).

On transaction capability, Zawislak et al. (2012) point out that once a company has developed a technology solution, it needs to be able to do whatever it takes to favor its transactions and sales. Along these lines, G_tax points out that the company "created markets that did not exist, created needs that perhaps the companies did not even know they had; they [...] did not even imagine that they could have so much tax loss due to not controlling the register correctly." Although the company acts with the advantage that its customers recognize the value of the service provided, and this alone favors the company's transactions, other actions related to transactions are not noteworthy within the company analyzed.

It is noted that the company has a combination of the four capabilities analyzed, and the technological development, operations, and managerial capabilities are impactful, ensuring that it is indeed innovative. In this case, it is possible to assess that the analyzed company has more technology-driven capabilities rather than business-driven ones. It is also possible to perceive the company's performance in the "entrepreneurial function" (relationship between technology development and operations capabilities), "technology management" (relationship between technology development and managerial capabilities), and "operations guarantee" (relationship between operations and managerial capabilities), as according to Zawislak et al. (2012).

\subsection{Systems Accounting Company}

The company analyzed has been in the market for 6 years and has stood out by offering a low-cost online financial control platform to an underexplored market segment (micro and small entrepreneurs), according to institutional documents. The exploration of digital technologies, such as digital platforms and cloud computing, allowed the company to create a new product to be offered in the market, financial control software, corroborating the research by Demirkan et al. (2016). Table 5 illustrates the strategic elements of the company analyzed. 
Table 5

Strategic elements of the systems business model

\begin{tabular}{|c|c|c|c|c|c|c|c|c|}
\hline $\begin{array}{l}\text { Customer } \\
\text { Segments }\end{array}$ & $\begin{array}{l}\text { Customer } \\
\text { Relationship }\end{array}$ & Channels & $\begin{array}{l}\text { Key } \\
\text { Features }\end{array}$ & $\begin{array}{l}\text { Key } \\
\text { Activities }\end{array}$ & $\begin{array}{l}\text { Key } \\
\text { Partnerships }\end{array}$ & $\begin{array}{l}\text { Cost } \\
\text { Structure }\end{array}$ & $\begin{array}{l}\text { Revenue } \\
\text { Sources }\end{array}$ & $\begin{array}{l}\text { Value } \\
\text { Proposition }\end{array}$ \\
\hline $\begin{array}{l}\text { Accountants } \\
\text { and micro } \\
\text { and small } \\
\text { businesses }\end{array}$ & $\begin{array}{l}\text { Focus on } \\
\text { the segment } \\
\text { served } \\
\text { (training and } \\
\text { support) }\end{array}$ & $\begin{array}{l}\text { Website, } \\
\text { online } \\
\text { platform, } \\
\text { and } \\
\text { phone }\end{array}$ & $\begin{array}{l}\text { Technology, } \\
\text { personnel, } \\
\text { and } \\
\text { marketing } \\
\text { resources }\end{array}$ & $\begin{array}{l}\text { System } \\
\text { maintenance, } \\
\text { upgrades and } \\
\text { improvement, } \\
\text { and customer } \\
\text { service }\end{array}$ & $\begin{array}{l}\text { Accountants } \\
\text { and } \\
\text { accounting } \\
\text { offices }\end{array}$ & $\begin{array}{l}\text { Personnel } \\
\text { and } \\
\text { technology }\end{array}$ & $\begin{array}{l}\text { Plans } \\
\text { ("packages") }\end{array}$ & $\begin{array}{l}\text { Information } \\
\text { organization } \\
\text { and control for } \\
\text { productivity } \\
\text { and } \\
\text { management }\end{array}$ \\
\hline
\end{tabular}

In this context, the company's technology development capability is noteworthy, enabling it to use digital technologies for strategic purposes, allowing for the creation of a new and unmarketed product: "we have the first cloudborn management system for small companies; we were the first company to offer automatic and banking integration [...] with a focus on data entry automation. We want the system [...] to be as simple and intelligent as possible" (G_sys). The technology development capability comes from the learning process, in which internal knowledge is exploited to produce technological changes that lead to new products and services (Zawislak et al., 2012).

The ability to operate these technologies is also identifiable within the enterprise. In this sense, G_sys highlights the importance of maintaining and constantly updating the platform to maintain product quality, as well as bringing more features to the product so that it keeps its prominent position in the market: "we have people improving the software every day, so we are offering more and more integrations, the [...] format of sending financial information to accounting is also evolving, we are always looking for new ways to be even more automated."

Regarding the managerial capability, G_sys highlights that management actions are focused not only on administrative issues, but also on improving the product offered: "our focus is on the user, so we need to streamline the traditional way of doing business, [...] to hire and for ERP in the past we needed a server, a license, and a technician to do the deployment and training, our software doesn't need any of that." The transaction capability, in turn, is evidenced by G_sys, who points out that the exploitation of digital technologies to create a new product and the organization of business has allowed "the practicing of lower prices than the traditional model, because it is less bureaucratic, less resources are needed and you can practice lower prices, scale [...] the business model and gain leadership." Still, G_sys underscores the importance of investing in marketing to conquer the market: "we work hard activating the needs of the public so that they see the advantages of using the management system."

It is observed that the company has a combination of the four capabilities analyzed, all of which are observed in the company. This confirms the innovative characteristics of the business, which allowed the company to gain over 800,000 customers in less than 6 years. In short, it is noted that the company analyzed has technology and business-driven capabilities, which makes its innovative capability more sustainable. Above all, it is possible to perceive the "technology selling" feature in the company, observed in the relationship between technology development and transaction capabilities (Zawislak et al., 2012). The exploration of new technologies enables the creation of new products, contributing to the continuity of the company.

\subsection{Forensic Accounting Company}

The company analyzed has been engaged in forensic accounting for a long time (over 50 
years) and innovates by using in-house software that supports the expert's work process and facilitates communication between clients and partners, as stated in institutional documents. One of the great features provided by the software is the updating of real-time proceedings between clients, experts, and lawyers. In addition, the system interface allows clients and experts to communicate quickly and easily. The company also develops innovative applications for this area (which will not be mentioned in the analysis so as not to hinder the development of this innovation). The strategic elements identified in the company are shown in Table 6.

Table 6

Strategic elements of the forensic business model

\begin{tabular}{|c|c|c|c|c|c|c|c|c|}
\hline $\begin{array}{l}\text { Customer } \\
\text { Segments }\end{array}$ & $\begin{array}{c}\text { Customer } \\
\text { Relationship }\end{array}$ & Channels & $\begin{array}{c}\text { Key } \\
\text { Features }\end{array}$ & Key Activities & $\begin{array}{c}\text { Key } \\
\text { Partnerships }\end{array}$ & $\begin{array}{c}\text { Cost } \\
\text { Structure }\end{array}$ & $\begin{array}{l}\text { Revenue } \\
\text { Sources }\end{array}$ & $\begin{array}{c}\text { Value } \\
\text { Proposition }\end{array}$ \\
\hline $\begin{array}{c}\text { Companies } \\
\text { and law } \\
\text { firms }\end{array}$ & $\begin{array}{l}\text { Close proximity } \\
\text { between the } \\
\text { company and } \\
\text { the customers } \\
\text { to collect case } \\
\text { information }\end{array}$ & $\begin{array}{c}\text { Email, } \\
\text { phone, } \\
\text { and online } \\
\text { platform (via } \\
\text { website) }\end{array}$ & $\begin{array}{c}\text { Technology } \\
\text { and } \\
\text { personnel }\end{array}$ & $\begin{array}{l}\text { Information } \\
\text { flow (process } \\
\text { distribution } \\
\text { and case } \\
\text { interpretation } \\
\text { for execution) }\end{array}$ & Law firms & Personnel & $\begin{array}{c}\text { Fixed } \\
\text { fee or } \\
\text { percentage } \\
\text { of results }\end{array}$ & $\begin{array}{l}\text { Financial } \\
\text { effect (gain } \\
\text { or loss } \\
\text { reduction) }\end{array}$ \\
\hline
\end{tabular}

From assessing these strategic elements, we once again note the presence of digital technologies supporting the business. Such technologies employed in accounting routines allow work processes to be more dynamic and secure (Bygren, 2016). The technology development capability of this company was most evident at the beginning of the business's operation, when technologies were installed and exploited to create software that would meet internal demands, as well as integrate and facilitate communication with clients and other partners: "our internal software is the tool that orients our work, it has been designed for the internal benefit of the organization" (Gaper).

The operations capability can currently be observed in the business, as the company seeks to efficiently operate the technology used to improve the quality of service provided (Zawislak et al., 2012). According to G_for, the software helps to bring more agility in conducting activities, since it is possible to follow all the progress of the processes in which the analyzed office operates: "here in the software we have all processes that we downloaded from the clients we have, so there is a massive amount of processes and data on expert calculations." This allows the company to provide quick results to customers and maintain different deadline controls.

This is made possible by the managerial capability, which sought new management methods and business strategies, such as the implementation of software that aided internal control and facilitated communication with customers and partners: "the software gives a better dimension and real-time working insights of how we work, so it allows us to better direct ourselves, and that makes us more efficient, [...] it is an advantage for us to have an online view of things" (G_for). Regarding transaction capability, it is noted that the company does not currently invest in this capability, which was more present when the software was implemented. Regarding the creation of online communication channels for customers and other partners: "whenever I have to send something or talk to my client, I will send or talk via the online communication channel provided by the software" (G_for).

It is verified that the company has a combination of the four capabilities analyzed, with the operations and managerial capabilities being 
the most present in the business today. These results are in agreement with the findings of Zawislak et al. (2012), showing that at the beginning of the activities of the company analyzed, the technology development capability predominated, then that capability migrated to operations and managerial capabilities according to changes that the company deemed necessary for the business. In this case, the capabilities of the company analyzed are focused on business rather than technology, evidencing the "operations guarantee" relationship, which is observed through the correlation between the operations and managerial capabilities (Zawislak et al., 2012).

\subsection{Audit Accounting Company}

The company analyzed innovates in how to provide its services to customers. It is a small company, founded in 2003, that uses automation technologies to assist in work processes and enable the execution of more efficient audit tests and analysis, according to the institutional documents. Table 7 illustrates the strategic elements identified in the company, which allow us to evaluate the way the company organizes and structures its business.

Table 7

Strategic elements of the audit business model

\begin{tabular}{|c|c|c|c|c|c|c|c|c|}
\hline $\begin{array}{l}\text { Customer } \\
\text { Segments }\end{array}$ & $\begin{array}{c}\text { Customer } \\
\text { Relationship }\end{array}$ & Channels & $\begin{array}{c}\text { Key } \\
\text { Features }\end{array}$ & Key Activities & $\begin{array}{c}\text { Key } \\
\text { Partnerships }\end{array}$ & $\begin{array}{c}\text { Cost } \\
\text { Structure }\end{array}$ & $\begin{array}{l}\text { Revenue } \\
\text { Sources }\end{array}$ & $\begin{array}{c}\text { Value } \\
\text { Proposition }\end{array}$ \\
\hline $\begin{array}{l}\text { Medium- } \\
\text { large sized } \\
\text { companies }\end{array}$ & $\begin{array}{c}\text { Close } \\
\text { relationship, } \\
\text { especially } \\
\text { with decision } \\
\text { makers }\end{array}$ & $\begin{array}{l}\text { Email, } \\
\text { reports, } \\
\text { and in } \\
\text { person }\end{array}$ & $\begin{array}{l}\text { Technology } \\
\text { and } \\
\text { personnel }\end{array}$ & $\begin{array}{l}\text { Work planning, } \\
\text { design, and } \\
\text { implementation } \\
\text { of audit tests } \\
\text { and reports }\end{array}$ & Law firms & $\begin{array}{l}\text { Personnel } \\
\text { and } \\
\text { opportunity } \\
\text { costs }\end{array}$ & $\begin{array}{c}\text { Technical } \\
\text { hours }\end{array}$ & $\begin{array}{c}\text { Assistance in } \\
\text { accounting, } \\
\text { tax, and } \\
\text { financial } \\
\text { matters }\end{array}$ \\
\hline
\end{tabular}

The use of digital technologies (especially automation technologies) has enabled the company to change its processes in order to automate much of the daily auditing work, which has brought more agility and security to the activities performed by the auditors (Bygren, 2016; Cokins \& Angel, 2017). Regarding this, G_aud highlights the following: "we use a lot of technological tools today; we use $\mathrm{R}$, which is a programing language, to create 'scripted' tests whenever possible." Along these lines, it is noted that the company has technology development capabilities. This enables the company to use digital technologies for strategic purposes to modify its processes and offer a high-quality service, with greater security and agility (Bygren, 2016).

This technology development capability reflects positively in operations capability. G_aud points out that new digital technologies have made it possible to reduce manual processes and automatize processes: "I have an action plan, a scripted work program, and I perform the tasks in there, [...] I do some tasks inside R, and some tasks outside, which are more manual, such as interviewing and process mapping jobs, but today most of our demand is going to the process automation line." This agility brought about by automation technologies allows the auditors to better focus on thinking and evaluating the client's business: "the accountant's own role is changing in a way, and we hope we have more time to think about how to predict problems, how to anticipate problems, how to control things" (G_aud).

Regarding managerial capability, G_aud points out that management actions are focused on administrative issues and the customization of the service provided: "most technology companies work with standardization, with a product that can be delivered to more customers at a lower cost, 
[...] we want to work with customization, and we differentiate ourselves precisely in the ability to plan tests as efficiently as possible for the specific customer problem." Regarding transaction capability, G_aud emphasizes seeking commercial strategies to sensitize the customer, pointing out the added value in the service provided: "with automation technologies we reduced a lot of work that was done in terms of handling databases [...] we now use this time to provide customer coverage, to help identify [...] what are the critical points of their business."

It is noted that the company has a combination of the four capabilities analyzed, with the technological development and operations capabilities being more impactful, ensuring that the company is indeed innovative. It is possible to observe that the company has technologydriven capabilities. Moreover, it is noted that the "entrepreneurial feature" stands out, which is observed through the relationship between the technology development and operations capabilities (Zawislak et al., 2012), where the exploitation of new technologies allows the creation of new operations, contributing to the company's innovativeness.

\subsection{Discussion}

Considering the strategic elements highlighted in the cases studied and their most prominent innovation capabilities, Figure 2 presents the results in relation to the composition of the companies' innovation capability in the various accounting areas. It illustrates the relationship between the innovation capabilities already present in the literature, the main practices that denote innovation capability, and which areas of accounting are evidencing this capability.

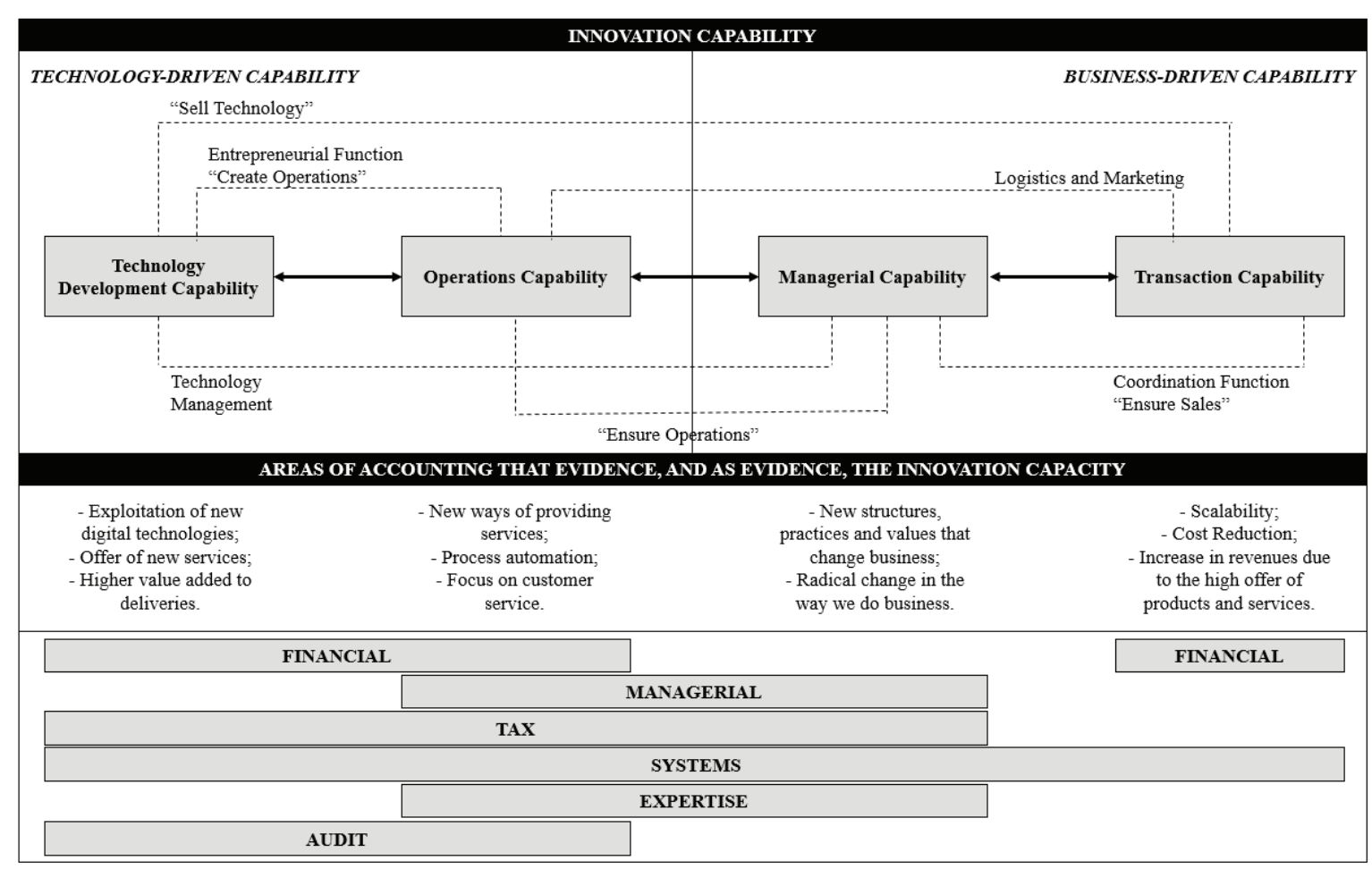

Figure 2. Systematization of the innovation capabilities of the accounting firms analyzed.

Source: Adapted from "Innovation capability: From technology development to transaction capability," by P. A. Zawislak, A. C. Alves, J. Tello-Gamarra, D. Barbieux, \& F.M. Reichert, 2012, Journal of Technology Management and Innovation, 7, p. 17. 
Accounting market innovation, mainly due to the different technologies that emerge to support and optimize accounting activities, is leading academics and market professionals to pay attention to the new business possibilities that emerge from this conjuncture (Guthrie \& Parker, 2016). In the case of the companies analyzed, it is noted that to some extent (since not all innovation capabilities are always verified), businesses have been able to digitally innovate by presenting new organizational structures in their business models, which allow the optimization of professionals' time and flexibility to perform higher value-added tasks (such as data analysis, for example), as well as offering new products and services to the market. However, the limitations for innovation, except in the systems area, are also presented: i) in the scalability of accounting activities, which provides cost reductions (given the efficiency resulting from the specialization of professionals in certain activities, and also the possibility of better input trading, considering bulk deals); and ii) the increase in revenues, due to the diversity and large quantity of products and services offered.

From examining the capabilities inherent in their innovation capability, the companies analyzed present, at first, only technology-based innovation capabilities (left side of Figure 2). From the cases analyzed, it is clear that these companies are following the trend of the digital innovation process (Nambisan et al., 2017), as presented by the different external documents. That is, there is the exploration of new digital technologies, working on the 'technology development capability' to take advantage of the innovation opportunities (products, services, and processes, among others) provided by these technologies (Hiningsa et al., 2018). It is also noted that the use of different technologies enables the analyzed companies to offer new services and products with higher added value for the client, as it was possible to verify in the recurrence of the terms 'data use,' 'consulting,' and 'customize/personalize' in the external documents analyzed (see Appendix 1).
It is noteworthy that the 'operations capability' was the only one observed in all the companies analyzed. This is because, although the companies analyzed deliver services similar to others in the market, considering the great normative influence of accounting activities, these businesses stand out in the way they provide their services, which is made possible, for example, by the support and use of different digital technologies in communication processes and other processes that characterize service delivery.

A second step in the development of innovation capability is that it was then possible to verify the movement from technology-driven capabilities to business-driven capabilities (to the right side of Figure 2). This move is consistent with the digital transformation process, which comprises a set of digital product, service, and process innovations; giving rise to new structures, practices, and values that change the business (Hiningsa et al., 2018).

Thus, it is noted that the companies analyzed at first worry about making the best use of information and digital technologies, and only then worry about a more radical change in their way of doing business, as can be observed by the presence of 'managerial capability.' This is because accounting is a very traditional branch of knowledge, so innovation tends to start with exploiting technology-driven capabilities and then involves building business-related modifications (Zawislak et al., 2012).

It warrants mentioning that the external documents analyzed concern mostly technologydriven capabilities, and business-driven capabilities are still barely discussed. Therefore, it can be noted that the 'transaction capability' of the accounting firms analyzed is still hardly verified. In this regard, only companies related to the financial and systems areas demonstrate this capability in a relevant way, since they are businesses that achieve scalability, cost reductions, and increased revenue; based on the characteristics of the products and services offered. 


\section{Final Considerations}

This research achieved its objective by examining the innovation capability of accounting firms in the Brazilian market that use digital technologies, based on technology development, operations, managerial, and transaction capabilities. In all companies analyzed, the presence of the four capabilities was identified, each of which is explored in different ways, considering the differences between each business model. These findings match the results of Zawislak et al. (2012, 2013), which reveal that companies have all four capabilities, that is, none of them is absent; however, for the company to be innovative, at least one of these four capabilities must be predominant.

It was observed that the most prevalent capabilities in the different cases studied are more geared towards technology than towards business, confirming the observation by Zawislak et al. (2012), who state that in innovative companies there is initially a predominance of the technology development or operations capability. In this sense, the results presented suggest that accounting has started on the path that traditionally moves towards digital innovation, confirmed by the changing trend of the accounting market, demonstrating the quality and value that solutions related to digital technologies can generate, due to these technologies being exploited in business, and especially in processes. It is also worth considering that this increase in technological artifacts has consequently caused changes in accounting business models, corroborating the studies by Baron (2016) and Basova (2017).

As limitations of this research, it is noted that, although it was not the intention of this research, only companies based in the southern region of Brazil were consulted. The study of companies from other locations may provide new findings on the topic discussed. Another limitation of the research lies on the fact that only the main manager of each company was interviewed. Interviews with other members of the companies, as well as interviews with clients, might have contributed to the subject with new discussion points. In addition, since they are specific cases, it is not possible to generalize the results highlighted. However, the results presented can be used to increase the body of theoretical knowledge on innovation and accounting. This is because they identify that the accounting industry is already on the way to innovation by adhering to the use of new technologies that allow the creation of new operations and the management of transactions.

Another contribution is the realization that the process of innovation and digital transformation already presents a real challenge to be managed by accounting firms, in an area that is considered traditional. The companies analyzed have already started using new digital technologies, focusing on accounting services innovation, and now they are moving towards digital transformation, creating new businesses from the innovation of higher value-added accounting products and services, which generate market gains and competitive advantage (Zawislak et al., 2012; Nylén \& Holmström, 2015). Thus, this research contributes to the field by presenting accounting business innovation trends involving new digital technologies, revealing how innovation capabilities are employed in contemporary and prominent cases in the market. Finally, the analyses performed in this research provide managers with a greater context regarding the changes in the current accounting environment, through the discussion related to new digital technologies and business innovation capabilities.

We suggest future studies to conduct research that seeks to identify factors that may be inhibiting the development of innovation capabilities in each accounting area. In addition, we suggest conducting research that seeks to identify the characteristics of accounting areas that facilitate this process of digital transformation. 


\section{References}

Abrell, T., Pihlajamaa, M., Kanto, L., Vom Brocke, J., \& Uebernickel, F. (2016). The role of users and customers in digital innovation: Insights from B2B manufacturing firms. Information \& Management, 53(3), 324-335.

Accenture (2015). Digital Density Index - Guiding digital transformation. Accenture Strategy.

Afuah, A.N. (2002) Mapping technological capabilities into product markets and competitive advantage'. Strategic Management Journal, 23 (2), 171-179.

Alves, A. C., Barbieux, D., Reichert, F. M., TelloGamarra, J., \& Zawislak, P. A. (2017). Innovation and dynamic capabilities of the firm: defining an assessment model. Revista de Administração de Empresas, 57(3), 232-244.

Baron, J. (2016). Disruptive trends accelerating for the accounting profession. Thomson Reuters.

Basova, A. (2017). Accounting-analytical model of innovation-active business entities. Advances in Economics, Business and Management Research, 38, 40-46.

Bonazzi, F.L.Z., \& Zilber, M.A. (2014). Inovação e modelo de negócio: Um estudo de caso sobre a integração do funil de inovação e o modelo canvas. Revista Brasileira de Gestão de Negócios, 16(53), 616-637.

Bygren, K. (2016). The digitalization impact on accounting firms business models. Thesis (Master of Science). School of Industrial Engineering and Management, Sweden.

Chandler, A. D. (1992). Organizational capabilities and the economic history of the industrial enterprise. Journal of Economic Perspectives, 6 (3), 79-100.

Chang, X., Hilary, G., Kang, J.K., \& Zhang, W. (2013). Does accounting conservatism impede corporate innovation? INSEAD Working Paper Series, 35, 01-46.

Coase, R. (1937). The nature of the firm. Economic, 4 (16), 386-405.

Cokins, G., \& Angel, S. (2017). The Disruptive Impact of the Digital Revolution on Accounting. Crunchbase - Icrunchdata.

Demirkan, H., Spohrer, J.C., \& Welser, J. (2016). Digital Innovation and Strategic Transformation. IEEE Computer Society, Guest Editors' Introduction, 14-18.

Eisenhardt, K., M. (1989). Building Theories from Case Study Research. Academy of Management Review, 14 (4), 532-550

Fawcett, T. (2015). The digital disruption. Academic Leadership Series, 6, 34-40.

Flick, U. Qualidade na pesquisa qualitativa. Porto Alegre: Artmed, 2009.

Frey, C.B., \& Osborne, M.A. (2013). The future of employment: how susceptible are jobs to computerisation? Oxford Martin School Working Paper.

Gibbs, G. (2009). Análise de dados qualitativos: coleção pesquisa qualitativa. Bookman Editora.

Gloet, M., \& Samson, D. (2016). Knowledge management and systematic innovation capability. International Journal of Knowledge Management, 12(2), 54-72.

Guan, J., \& Ma, N. (2003). Innovative capability and export performance of Chinese firms. Technovation, 23, 737-747.

Guthrie, J., \& Parker, L.D. (2016). Whither the accounting profession, accountants and accounting researchers? Commentary and projections. Accounting, Auditing \& Accountability Journal, 29(1), 02-10. 
Hess, T., Matt, C., Wiesböck, F., \& Benlian, A. (2016). Options for Formulating a Digital Transformation Strategy. MIS Quarterly Executive, 15(2), 01-02.

Hinings, B., Gegenhuber, T., \& Greenwood, R. (2018). Digital innovation and transformation: An institutional perspective. Information and Organization, 28(1), 52-61.

Kane, G. C., Palmer, D., Phillips, A.N., Kiron, D., \& Buckley, N. (2015). Strategy, Not Technology, Drives Digital Transformation. MIT Sloan Management Review and Deloitte University Press, 01-27.

Kim, L. (1999). Building technological capability for industrialization: analytical frameworks and Korea's experience. Industrial and Corporate Change, 8 (1), 111-136.

Laforet, S. (2011). A framework of organizational innovation and outcomes in SMEs. International Journal of Entrepreneurial Behavior \& Research, 17(4), 380-408.

Lawson, B., \& Samson, D. (2001). Developing Innovation Capability in Organisations: A Dynamic Capabilities Approach. International Journal of Innovation Management, 5(3), 377-400.

Liu, D.Y, Chen, S.W., \& Chou, T.C. (2011). Resource fit in digital transformation: Lessons learned from the CBC Bank global e-banking project. Management Decision, 49(10), 17281742.

Mintzberg, H. (1979). An Emerging strategy of "direct" research. Administrative Science Quarterly, 24, 580-589.

Nambisan, S. (2013). Information technology and product/service innovation: A brief assessment and some suggestions for future research. Journal of the Association for Information Systems, 14(4), 215-226.
Nambisan, S., Lyytinen, K., Majchrzak, A., \& Song, M. (2017). Song Digital innovation management: Reinventing innovation management research in a digital world. MIS Quarterly, 41(1), 223-236

Nylén, D., \& Holmström, J. (2015). Digital innovation strategy: A framework for diagnosing and improving digital product and service innovation. Business Horizons, 58(1), 57-67.

Osterwalder, A., \& Pigneur, Y. (2011). Business model generation: inovação em modelos de negócios. Rio de Janeiro: Alta Books.

Pan, G., \& Seow, P.S. (2016). Preparing accounting graduates for digital revolution: a critical review of information technology competencies and skills development. Journal of Education for Business, 91(3), 166-175.

Rajapathirana, R.J., \& Hui, Y. (2017). Relationship between innovation capability, innovation type, and firm performance. Journal of Innovation \& Knowledge, 3(1), 44-55.

Reichert, F.M.; Beltrame, R.S; Corso, K.B.; Trevisan, M., \& Zawislak, P. A. (2011). Technological Capability's Predictor Variables. Journal of Technology Management \& Innovation, $6(1), 14-25$.

Richardson, G. (1972). The organization of industry. Economic Journal, 82 (327), 883-896.

Schreier, M. (2013). Qualitative content analysis. In U. Flick (Ed.), The SAGE handbook of qualitative data analysis. London: Sage, 170-183.

Sebastian, I.M., Ross, J.W., Beath, C., Mocker, M., Moloney, K.G., \& Fonstad, N. O. (2017). How Big Old Companies Navigate Digital Transformation. MIS Quarterly Executive, 16(3), 197-213.

Slater, S.F., Hult, G. T.M., \& Olson, E.M. (2010). Factors influencing the relative importance of marketing strategy creativity and marketing 
strategy implementation effectiveness. Industrial Marketing Management, 39(4), 551-559.

Tongur, S., \& Engwall, M. (2014). The business model dilemma of technology shifts. Technovation, 34(9), 525-535.

Williamson, O. (1985). The Economic Institutions of Capitalism. Free Press, New York. 450p.

Yin, R.K. (2015). Estudo de caso: planejamento e métodos. 5. ed. Porto Alegre: Bookman.
Zawislak, P.A., Alves, A.C., Tello-Gamarra, J., Barbieux, D, \& Reichert, F.M. (2012). Innovation capability: From technology development to transaction capability. Journal of Technology Management \& Innovation, 7(2), 14-27.

Zawislak, P.A., Alves, A.C., Tello-Gamarra, J., Barbieux, D., \& Reichert, F.M. (2013). Influences of the internal capabilities of firms on their innovation performance: a case study investigation in Brazil. International Journal of Management, 30(1), 329. 


\section{Appendix 1}

Handling and manipulation of external documents in Nvivo and word cloud of external documents.

External documentary data were processed and manipulated in the Nvivo 11 software. Initially, the aim was to homogenize the language of the 47 external documents. As most of the documents were international, those documents that were in Portuguese were translated into English. Subsequently, all documents were transferred to the Nvivo 11 software to allow for the analysis of the content of these documents. Another analysis performed with the external documents was the survey of the frequency of the terms in these documents, which could be evaluated by counting them and by their respective weighted percentages. One way of representing this data is by systematizing the most frequent terms in a word cloud, presented below and elaborated with the Nvivo 11 software. Note that, for this analysis, we used the filter "grouping of synonym words." The discussion of the word cloud results is held in section 4.7.

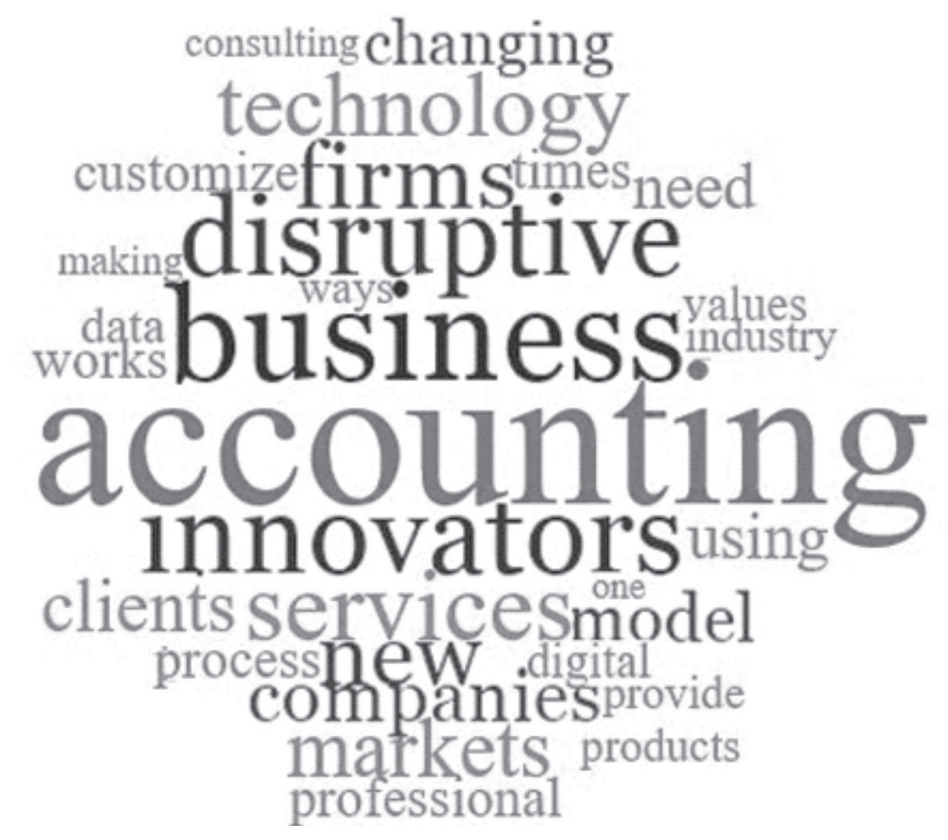




\section{Appendix 2}

Code book: The coding framework was built from codes derived from the literature on innovation capabilities by Zawislak et al. (2012) and the literature on the strategic elements of business models (Osterwalder \& Pigneur, 2011).

\begin{tabular}{|c|c|c|}
\hline Code & Description & Application \\
\hline $\begin{array}{l}\text { Technology } \\
\text { Development } \\
\text { Capability }\end{array}$ & $\begin{array}{l}\text { Anyone's ability to interpret the current } \\
\text { state of art and absorb and eventually } \\
\text { transform a particular technology to } \\
\text { create or alter its capability to operate, } \\
\text { as well as any other capability to achieve } \\
\text { higher levels of technical and economic } \\
\text { efficiency. }\end{array}$ & $\begin{array}{l}\text { "It was through new technologies that we were able to offer the } \\
\text { service we offer today, in the cloud, to thousands of companies and } \\
\text { in various cities across the country, which was not possible before } \\
\text { without these technologies." } \\
\text { G_fin }\end{array}$ \\
\hline Operations Capability & $\begin{array}{l}\text { The ability to execute productive } \\
\text { capability, which is shown through the } \\
\text { assortment of daily routines that are } \\
\text { embodied in knowledge, skills, and } \\
\text { technical systems at any given time. }\end{array}$ & $\begin{array}{l}\text { "Technology is fundamental to the work we do, and it is } \\
\text { fundamental as a means. For example, the relationship channel we } \\
\text { use is an online platform where the customer logs in and places } \\
\text { their entire request, and we have a maximum of } 24 \text { hours to } \\
\text { answer." } \\
\text { G_man }\end{array}$ \\
\hline
\end{tabular}

G_man

"I have already worked in other offices, so I saw that people wanted to deliver what they wanted, and the customer didn't want what was being delivered, so we reversed that logic, we listen to

Managerial

Capability

The ability to transform the result of technological development into coherent operations and transaction arrangements.

business."

G_man

\begin{tabular}{lll}
\hline \multirow{2}{*}{$\begin{array}{l}\text { Transaction } \\
\text { Capability }\end{array}$} & $\begin{array}{l}\text { The ability to reduce marketing, } \\
\text { outsourcing, trading, logistics, and } \\
\text { delivery costs; in other words, transaction } \\
\text { costs. }\end{array}$ & $\begin{array}{l}\text { "Lower prices than the traditional model, because it reduces } \\
\text { bucracy, drives the machine and you can practice lower prices, } \\
\text { G_sys }\end{array}$ \\
\hline \multirow{2}{*}{ Customer Segments business model and gain leadership." } \\
& $\begin{array}{l}\text { An organization serves one or more } \\
\text { Customer Segments in the market. }\end{array}$ & $\begin{array}{l}\text { "XXX's customer type is the micro and small business owner." } \\
\text { G_sys }\end{array}$ \\
\hline
\end{tabular}

"I would say XXX was a pioneer in paying attention to this audience and in developing a system for this audience. [...] We come to the market with a proposal: for $\mathrm{R} \$ 29.00$ (around \$ 6.75), the small business owner can have a system running in the

Customer Relationship

Customer Relationship is established and maintained with each Customer Segment. company, with free training and support, no implementation costs, completely online, without having to purchase a server." G_sys

"With the software the entrepreneurs will learn how to make sales, they will learn how to generate a contract, how to issue a ticket and invoices, how to integrate all the bank information into the management system, register bank transactions, register customers, register products, so that they can have a view of their company's reports, things they will not have in the notebook. The software brings together everything a business owner needs." G_sys customers through Communication, Distribution, and Sales Channels.

"Marketing resources [...], then people resources, for all service Key Features Key Features are the active elements to areas, and then all service availability and system availability resources, which are server resources." provide and deliver planned activities. G_sys

A number of Key Activities are Key Activities performed to provide and deliver planned activities. 


\begin{tabular}{|c|c|c|}
\hline Code & Description & Application \\
\hline Key Partnerships & $\begin{array}{l}\text { Some activities are outsourced, and } \\
\text { some resources are acquired outside the } \\
\text { company. }\end{array}$ & $\begin{array}{l}\text { "Not only with accountants, but also with government, with banks } \\
{[\ldots] . "} \\
\text { G_sys }\end{array}$ \\
\hline Cost Structure & $\begin{array}{l}\text { The different elements of the business } \\
\text { model result in Cost Structure. }\end{array}$ & $\begin{array}{l}\text { "First comes people, and second is server infrastructure so we can } \\
\text { keep it all in the cloud." } \\
\text { G_sys }\end{array}$ \\
\hline Revenue Sources & $\begin{array}{l}\text { Revenue Sources are the result of Value } \\
\text { Propositions successfully offered to } \\
\text { customers. }\end{array}$ & $\begin{array}{l}\text { "Scale is a watchword here for us. So it's a monetization model that } \\
\text { does need scale, via monthly payments." } \\
\text { G_sys }\end{array}$ \\
\hline Value Proposition & $\begin{array}{l}\text { Seeks to solve customer problems } \\
\text { and satisfy their needs with Value } \\
\text { Propositions. }\end{array}$ & $\begin{array}{l}\text { "XXX's customer type is the micro and small business owner." } \\
\text { G_sys }\end{array}$ \\
\hline
\end{tabular}


Supporting Agencies: CAPES and CNPq

\section{Authors:}

1. Giovana Sordi Schiavi, Master's Degree, Federal University of Rio Grande do Sul, Business School, Rio Grande do Sul, Brazil. E-mail: giovanaschiavi@hotmail.com

ORCID

(iD) 0000-0002-8032-5598

2. Fernanda da Silva Momo, PhD, Federal University of Rio Grande do Sul, Business School, Rio Grande do Sul, Brazil. E-mail: fernandamomo@yahoo.com.br

ORCID

(iD) 0000-0002-6512-5280

3. Ariel Behr, PhD, Federal University of Rio Grande do Sul, Business School, Rio Grande do Sul, Brazil. E-mail: ariel.behr@ufrgs.br

ORCID

(iD) 0000-0002-9709-0852

4. Antonio Carlos Gastaud Maçada, PhD, Federal University of Rio Grande do Sul, Business School, Rio Grande do Sul, Brazil. E-mail: acgmacada@ea.ufrgs.br

ORCID

(D) 0000-0002-8849-0117

\section{Contribution of each author}

\begin{tabular}{lccc}
\hline Contribution & $\begin{array}{c}\text { Giovana } \\
\text { Schiavi }\end{array}$ & $\begin{array}{c}\text { Fernanda } \\
\text { Momo }\end{array}$ & $\begin{array}{c}\text { Ariel Behr } \\
\text { Antonio } \\
\text { Maçada }\end{array}$ \\
\hline $\begin{array}{l}\text { 1. Definition of research problem } \\
\text { 2. Development of hypotheses or research questions (empirical studies) }\end{array}$ & $\sqrt{ }$ & $\sqrt{ }$ & $\sqrt{ }$ \\
3. Development of theoretical propositions (theoretical Work) & $\sqrt{ }$ & $\sqrt{ }$ & $\sqrt{ }$ \\
4. Theoretical foundation/ Literature review & $\sqrt{ }$ & $\sqrt{ }$ & $\sqrt{ }$ \\
5. Definition of methodological procedures & $\sqrt{ }$ & $\sqrt{ }$ \\
6. Data collection & & $\sqrt{ }$ & $\sqrt{ }$ \\
7. Statistical analysis (not apply to article) & & $\sqrt{ }$ \\
8. Analysis and interpretation of data & & $\sqrt{ }$ \\
9. Critical revision of the manuscript & $\sqrt{ }$ \\
10. Manuscript Writing & & $\sqrt{ }$ \\
11. Other (please specify which) & & $\sqrt{ }$ \\
\hline
\end{tabular}

